\title{
A STUDY OF THE HISTORICAL CONSTRUCTION TECHNOLOGY OF BELL TOWERS IN CYPRUS
}

\author{
MARGARITA L. PETROU ${ }^{1 *}$ AND DIMOS C. CHARMPIS ${ }^{1}$ \\ ${ }^{1}$ Department of Civil and Environmental Engineering, University of Cyprus \\ 75 Kallipoleos Str., P.O. Box 20537, 1678 Nicosia, Cyprus \\ e-mails: mpetro03@ucy.ac.cy (*corresponding author), \\ charmpis@ucy.ac.cy
}

Keywords: Construction Technology, Stone Masonry, Earthquake Engineering, Historical Survey, Slender Structures

\begin{abstract}
This paper aims to present the historical construction technology of churches' bell towers in Cyprus, starting with the initiation of their use and addressing the development of their distinctive morphology adapting and mixing various architectural styles. Traditional bell towers are tall and slender unreinforced masonry structures that are known to be particularly vulnerable to earthquake actions encountered in seismogenic regions, such as Cyprus. Therefore, iron and wood elements with high tensile capacities were commonly utilized in Cypriot bell towers in the form of ties. In particular, the bell tower of Saint John's church in Psevdas village was constructed using such technology and is an example case studied in more detail in the present work. This tower suffered a partial collapse during an earthquake on May 12th, 2016 and underwent restoration within the next year. Based on the knowledge gathered from the case of the damaged tower and the visual inspection of other bell towers in Cyprus, the use of timber and iron ties in these masonry structures is deemed to be essential for their protection from seismic actions.
\end{abstract}

\section{INTRODUCTION}

Building seismic resistant structures has always been of major importance in seismogenic regions, such as Cyprus. Tall and slender unreinforced masonry structures, such as the bell towers of churches, have proven to be particularly vulnerable to seismic actions. Taking this fact into consideration, various specialized construction and intervention technologies have been developed throughout history to enhance the seismic resistance of such masonry structures. For this purpose, construction materials associated with high tensile capacities, such as iron and wood, were commonly utilized in the form of ties. Such technology was used for the construction of the bell tower of the Saint John's church in Psevdas village, Cyprus. The particular about 100-year-old stone masonry bell tower suffered a partial collapse on the 12th May 2016, when an earthquake of magnitude 4.5 Richter struck the southeastern part of Cyprus [1].

The present study was triggered by the restoration process of the aforementioned damaged tower and aims in providing an overall review of the historical construction technology of bell towers in Cyprus. Hence, this paper first reports an overview regarding the initial and thereafter 
the regular use of bells and bell towers in Cyprus. Next, the morphology of traditional Cypriot bell towers and their susceptibility to earthquake hazard are addressed. Following a rigorous visual inspection of various bell towers in Cyprus, including the bell tower in Psevdas presented herein in more detail, it can be deduced that the use of timber and iron ties in such masonry structures is essential for their protection from seismic actions.

\section{INITIAL AND REGULAR USE OF BELLS AND BELL TOWERS}

\subsection{Origin of bells and bell towers}

Bells are idiophone instruments made of bronze. Since antiquity, various civilizations used bells for both ritual and practical purposes. It is uncertain when precisely the use of bells became part of the Christian tradition. However, the need for a means to summon the people to the church and regulate monastic life appeared since the early years of Christianity. The development of the semantron (metal or wooden strip knocked with a hammer) [2], which was broadly used in the monasteries - and is actually still in use in the orthodox monasteries - and generally in the eastern church, came to satisfy this need.

The first uses of bells are tracked in the West around the 6th century. The Latin name for bell 'campana' derives from the region of Italy, Campania, where bells were first used in the church [3]. During the reign of Pope Sabinian (604-606), the use of bells was adopted by the western church. Gradually, due to the popularity of bells during the Carolingian period, the

need emerged to develop specially dedicated
realization that the ring sound of the bells w
altitudes led to the development of the bell tov
is the one raised by Pope Stephen II (752-757)
2.2 Bells and bell towers in Byzantium
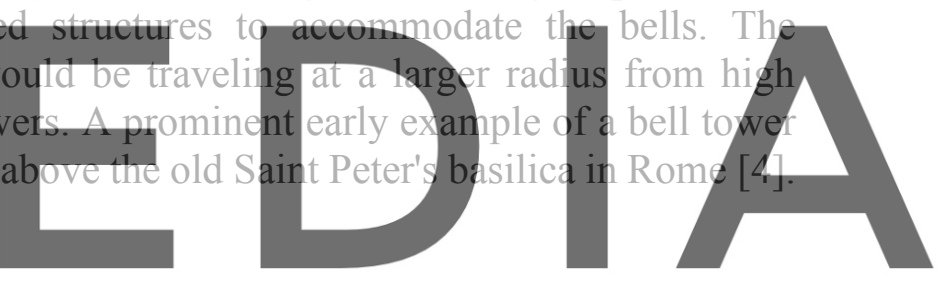

The origin of bells' use and thus the construction of bell towers in the Byzantine East is even

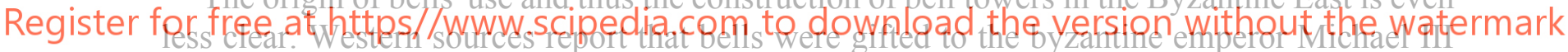

(842-867) by the Venetian Doge Ursus I Partecipazio (864-881) as a gesture of gratitude for assisting the Venetians to defeat the Arabic troops in Daimatia [4] [5]. These belis were raised on a tower in the yard of Hagia Sophia, in Constantinople [2]. Though, as the use of the semantron was a point of differentiation between the two principal dogmas of Christianity, the use of bells popularized only during the occupation of Constantinople by the Latins (12041261) [4]. Bells were ringing in Constantinople until its fall (May $29^{\text {th }}, 1453$ ), after the siege by the Ottomans.

Ottomans looted the areas they conquered, destroying bell towers and turning churches into mosques. Thereon, the Islamic law enforced by the conquerors was not only the personal law for the Muslims, but also the state law for all inhabitants of the empire, regardless of their religion. The Christian church, as was the case also with other religious groups of the empire, was granted privileges for administrative reasons. However, various restrictions were imposed. These included the ban of bell ringing and posting of the cross on churches [5]. Alongside, the construction of new churches and bell towers was prohibited (with few exceptions), while only the preservation and renovation of the existing churches was allowed [6]. 


\subsection{Bells and bell towers in Cyprus}

In 1571, Ottomans conquered Cyprus and imposed the same restrictions for the ecclesiastical constructions. Due to the bell ringing ban, the semantron returned in use for summoning the people to the church. Kokkinoftas [5] reported that the first bell imported in Cyprus during the Ottoman period was most probably the bell of Holy Cross church in Omodos village (Fig. 1) situated at Limassol district. An inscription dates the bell back to 1812. In 1839, the Sultan proclaimed reforms for the reorganization of the empire with the issuance of Gülhane Hatt-1 Şerif edict. Hence, some bells, gifted by Cypriots living in Venice, were raised on churches around the island. Ottoman authorities consented for the use of the bells; still, there were opposing reactions by the Muslim population [5].
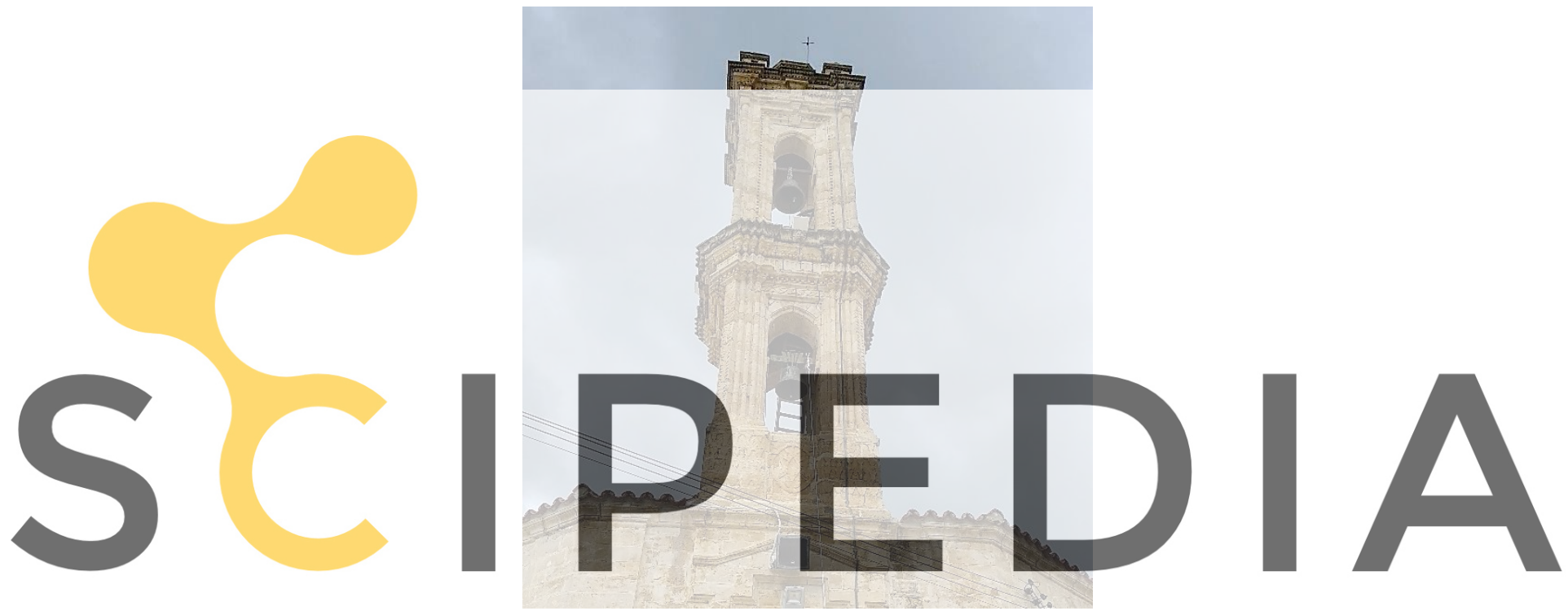

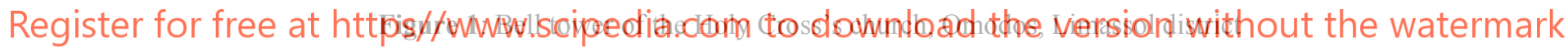

In 1856, the Ottoman Imperial rescript Hatt-i Hümayun eventualiy recognized the right of all non-Muslim communities to administer their religious affairs. The reforms stipulated by the rescript raised the nationalism of the local population, as their religious leader (the Archbishop of Cyprus) also became the national leader, concentrating both religious and civil authorities under the millet system applied in the Ottoman Empire [7]. The rescript also lifted the bell ringing ban, leading to several bell tower erections in numerous existing churches [8]. Thereon, all new churches constructed in Cyprus bear at least one bell tower.

\section{MORPHOLOGY OF THE CYPRIOT BELL TOWERS}

\subsection{Architectural style}

The events of the Cypriot history have influenced the ecclesiastical architecture of Cyprus. As a part of the Orthodox East, the Byzantine style and standards were always an integral part of the ecclesiastical architecture. During the Frankish period (1191-1489), however, the pointed gothic arch was adopted and embodied in the traditional architecture, leading to the 
development of a combined style. This style is the so-called Franko-Byzantine style by some authors [9]. During the Ottoman period, due to the restrictions imposed, the style was simplified to single nave pointed vaulted churches with low windows and buttresses.

The liberation of the religious affairs and practices resulted in the development of a new architectural style, the Cypriot Neo-Gothic style, which appeared first on the newly constructed bell towers and later transferred to new churches. The combination of Neo-Gothic towers with churches of Byzantine or Franko-Byzantine style is a frequent phenomenon in Cyprus. A notable example of this is the church of Saint Lazarus in Larnaca. The massive multi-dome Byzantine basilica was built with the funding of the byzantine emperor Leo VI (866-912) in the 890s. In 1857, a bell tower following the Italian standards was added on the southside of the chancel [10]. The bell tower is $23 \mathrm{~m}$ tall and bears detailed carved ornamentation and two belfry storeys (Fig. 2).

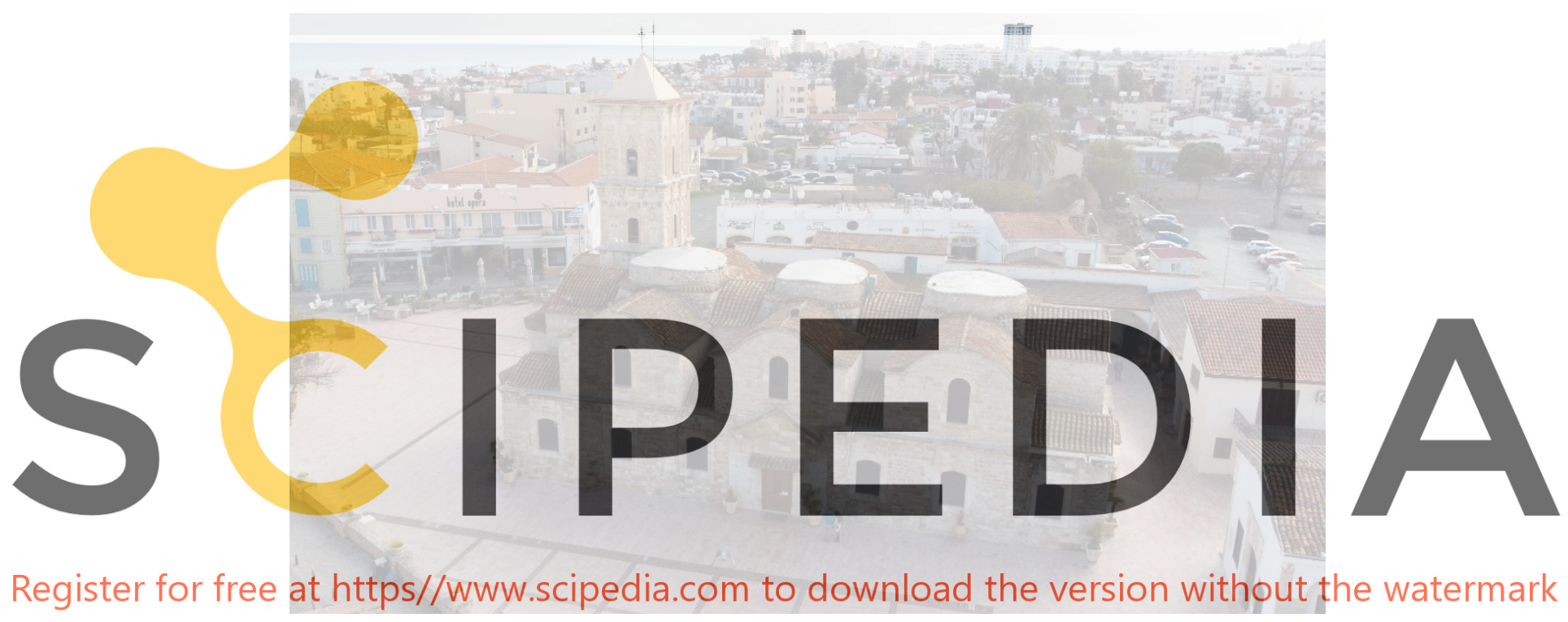

Figure 2: Church of Saint Lazarus, Larnaca

The Cypriot Neo-Gothic style (1850s-1930s), similarly to the international Gothic revival of the mid-19th century [11], symbolizes the religious freedom and the formation of the national identity of the Cypriots. The main characteristic of the Cypriot Neo-Gothic is the elaborate carved ornamentation of the bell towers and the lintels. Often, Neo-Gothic features are mixed with Neo-Classical - such as at pediments and columns - as well as with Neo-Byzantine and Eclectic features. The use of the Neo-Byzantine style was accented in the 1930s, following the influence of architects descending from Greece. The later added towers were not consistent with the architectural style of the church they were attached to.

\subsection{Form and structure}

A typical bell tower has a four-part structure. First, a strong base provides support and stability to the tower. Second, the shaft is the part primarily intended for attaining the desired height of the tower and contains stairs leading to the belfry. The third part is the belfry, in which the bells are housed, and it is often the most decorated part. Finally, the tower is completed at 
the top with a roof.

The tall (over $30 \mathrm{~m}$ in height) famous Italian campanili usually stand at a distance from their corresponding church [12]. Unlike these towers, Cypriot bell towers do not exceed $30 \mathrm{~m}$ in height, with their free-standing height often being within the range 10-15 m. As such towers were later supplements to existing churches, any newly added tower was based on and sat atop the main body of the church or it was attached to the exterior of the church, at one of the four corners of the rectangular main structure. New churches built after 1856 usually included bases for one or two bell towers as part of the church's structure.

It is unclear where the morphology of the early Cypriot bell towers derived from. Kiessel and Tozan [8], who studied the architecture of the Cypriot bell towers from the mid-19th century to 1974 , noted that their typology showed significant similarity to the 16th century Italian Renaissance predecessor, as it appears in the 'Wedding at Cana' by Veronese (15601563). Actually, there is a general sense that monumental paintings in local churches dating back to the period of the Venetian rule might have influenced the form of Cypriot bell towers [13]. Hence, a bell tower usually consists of a solid base, up to four storeys divided by entablatures and a canopy at the top. If the tower is attached to the church's body, the solid base reaches the height of the wall cornice [8]. Each storey is formed by four pillars and arched openings at all four sides. The upper one or two storeys are the belfries of the tower. Usually, each belfry bears one bell, which hangs from an iron bar anchored into the pillars.

Between 1856 and the 1930s, the primary material used for the construction of the towers was limestone masonry. In the 1940s, the use of reinforced concrete gradually spread, replacing stone masonry. The form and structure of the bell towers follows the typical typology described firstly. The example of historical centre of construction material. T and regular masonry blo tower designed by the architect Theodoros Photiades, the first Cypriot architect, was built as a

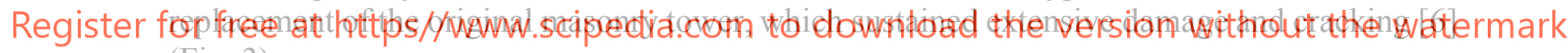
(Fig. 3).
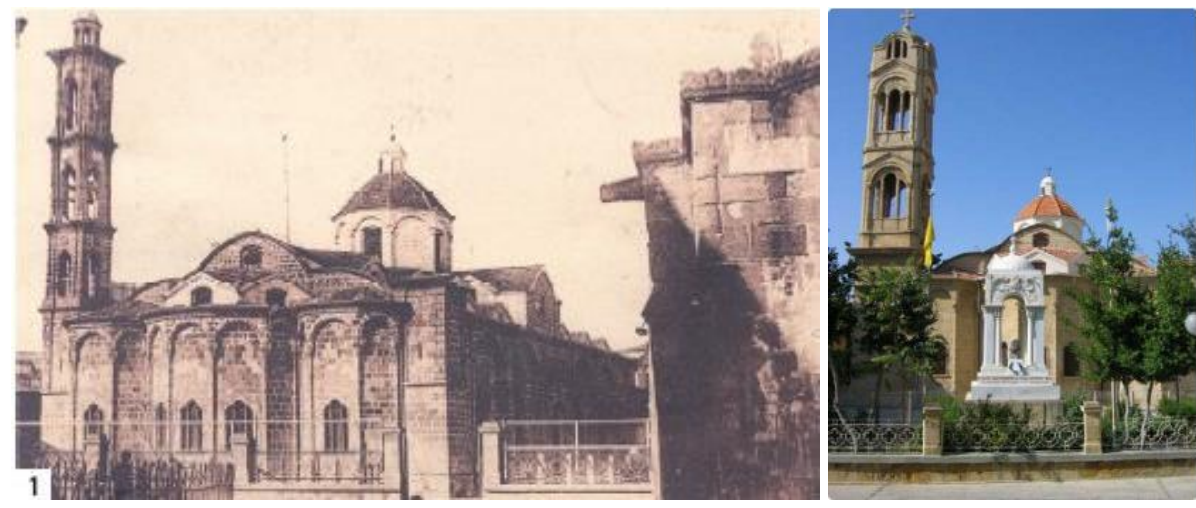

Figure 3: The old masonry (left) [6] and current concrete (right) [15] bell tower of the church of 'Panagia Faneromeni', Nicosia 


\section{EARTHQUAKES VS. CYPRIOT BELL TOWERS}

The island of Cyprus sits to the north of the boundary where the African and Eurasian tectonic plates meet. The seismic activity of the local 'Cyprean arc' has been the cause of numerous devastating earthquakes on the island. Many settlements and masonry structures, in particular, have collapsed as a result of seismic actions since antiquity [16]. According to the records of the Cyprus Geological Survey Department, an earthquake of magnitude 7.0 Richter (VIII-IX Mercalli) struck the island in 1491, causing extensive damage to Hagia Sophia cathedral, in Nicosia. Other significant seismic events (of average magnitude 6.5 Richter and V-IX Mercalli) occurred in 1577, 1735, and 1896, causing damages and casualties.

In 1906, the earthquake that struck Limassol area (magnitude 5.6 Richter/VIII Mercalli) caused damage to many buildings, among which was the cathedral of Hagia Napa and its bell towers [17]. During the last 100 years, the most significant event occurred in 1953, when the damage caused by the earthquake of magnitude 6.5 Richter (IX Mercalli) in the district of Paphos was very severe, leaving, numerous masonry and concrete structures destroyed and resulting in several casualties and homeless people [18] (Fig. 4).
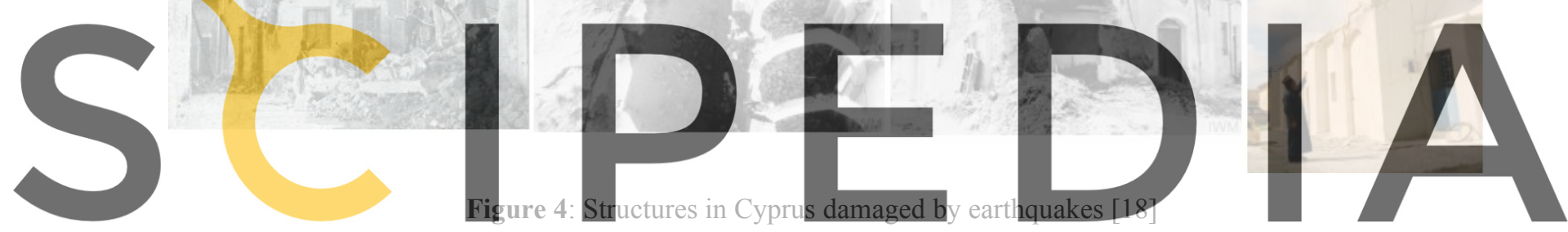

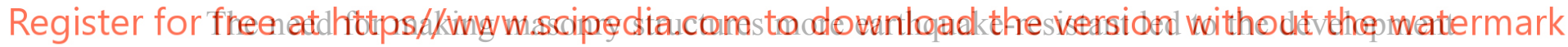
of various relevant construction and intervention technologies. Among such technologies, the installation of iron and timber ties has been often used as an effective way to better cope with the earthquake hazard in Cyprus [19]. Hence, tie-rods were installed during the initial construction phase on the arches of bell towers, as well as on opposite walls of the churches' main body. The use of timber tie-rods in Cyprus is minimal. An outstanding example application of this technique employing timber ties is on the bell tower (built in the 1890s) of archbishopric cathedral of Saint John (built in 1662) in Nicosia [20] (Fig. 5). On the other hand, the use of iron tie-rods was more popular and many example applications can be found in various regions of the island. Moreover, iron ties (cramps) were occasionally installed between the storeys of the bell tower, in order to better fasten the entablatures.

Various previous studies focused on examining the effectiveness of tie-rods and their contribution in the seismic response of a structure [19] [21]. Kouris and Kouris [22] specifically studied the influence of tie-rods on the seismic behavior of slender towers. In all relevant studies, there appears to be a consensus regarding the effect of tie-rods on structural behavior: such ties promote integral behavior and result in increased seismic resistance for the tied up structural system [23]. In light of the above, the use of tie-rods in various constructions by Cypriot master craftsmen even more than a century ago reveals these workers' awareness and 
concern regarding the high significance of the seismic hazard for the island's buildings stock.

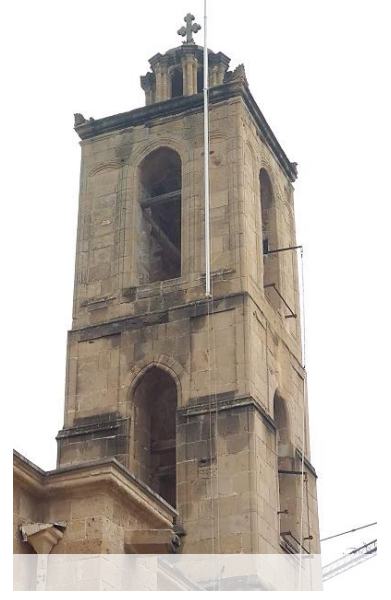

5 THE CASE OF SAINT JOHN'S BELL TOWER IN PSEVDAS VILLAGE

Saint John's church was built in 1897 as a renovation and extension of an older church dating back in 1780 (date noted on the chancel's outer wall). Later, in the 1910s, a bell tower on the southside of the chancel was ereeted following the Cypr tower collapsed due to an earthquake on May $11 \mathrm{~km}$ west of Larnaca and mainshock was 4.5 Rich Thankfully, there were no casualties from the the morning. The chureh is located at Psevdas
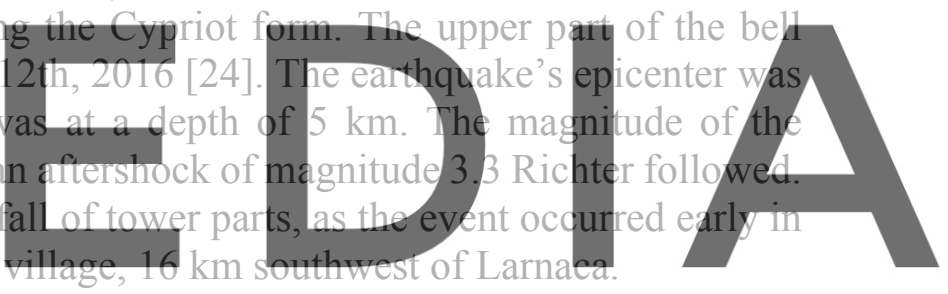

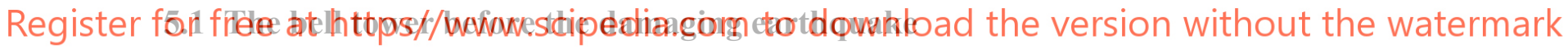

Before the earthquake, the bell tower of Saint John's church consisted of: (a) a solid base built on top of the church's main body at the southside, (b) four masonry pillars connected with arches - in all four sides - in two storeys divided by entablatures and (c) an arched octagonal canopy. The upper storey was used as a belfry for one bell. The height of the tower's parts was: about $1.5 \mathrm{~m}$ for the base, $2 \mathrm{~m}$ for each storey and $1.5 \mathrm{~m}$ for the canopy. The cumulative height was $14 \mathrm{~m}$ from the ground or $7 \mathrm{~m}$ from the cornice of the church's masonry (free-standing height). The horizontal cross-section of the base and the storeys was about $1.70 \times 1.70 \mathrm{~m}^{2}$, while the storeys' entablatures had a central hole of $0.60 \times 0.60 \mathrm{~m}^{2}$. The canopy covered the hole of the upper entablature.

Typically, the preferable way of construction in Cyprus in the past was by utilizing locally available materials. Hence, the masonry of the particular bell tower was built of natural white limestone (compact chalk), coming from the nearby Lympia village, and lime mortar. The main body of the church is of masonry made by cobbels taken from the nearby river. Limestone was a popular building material due to its softness and the ease it provided in carving upon the masonry. Another frequent practice was the use of impermeable cementitious material on the exposed upper surfaces for waterproofing purposes. The canopy's roof and the surface of the 
upper entablature were covered with such material.

As regards the architectural style aspect, the decoration of the tower combined at least two distinctive styles. The carved ornamentation on the pillars, the cornice of the entablatures and four acroteria placed on the upper entablature followed the Neo-Classical style, while the decoration of the arches and the canopy followed the Neo-Gothic style. In contrast to the elaborate decoration of the tower, the church was a Neo-Gothic single-nave basilica with minor decoration.

\subsection{The bell tower after the damaging earthquake}

The earthquake caused the collapse of the canopy, the three out of four acroteria and a large part of the upper entablature. Only two out of eight pillars of the canopy's arches were standing after the earthquake (Fig. 6). Most of the fallen parts turned into rubble.

During the visual in situ inspection of the damaged bell tower of Saint John's church, it was found that iron tie-rods connect the intrados of the arches of the two storeys, while a grid of four iron camps fasten each storey at the height of each entablature (Fig. 6). The bell hangs from an iron bar anchored into the masonry pillars. There is another iron cramp just beneath the bell, which protects the masonry from the mechanical action (erosion) caused by the friction between the bell's rope and the stone. All metal elements were installed during the initial construction phase using gypsum mortar.
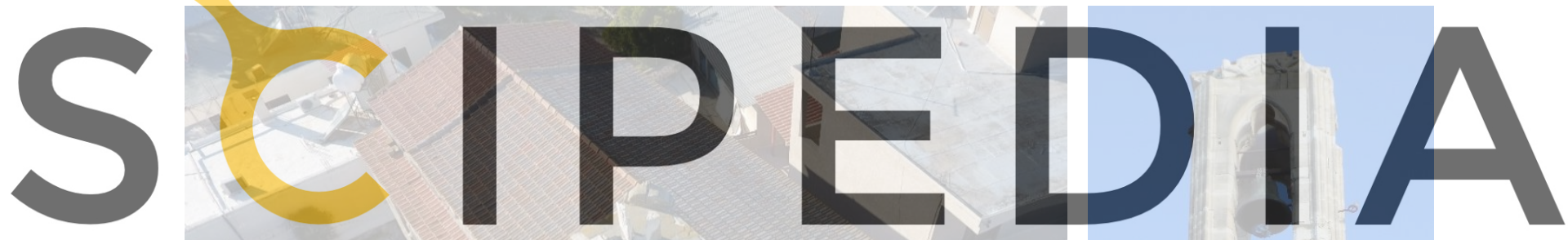

Register for free at https//www.scipedia.com to download the version without the watermark
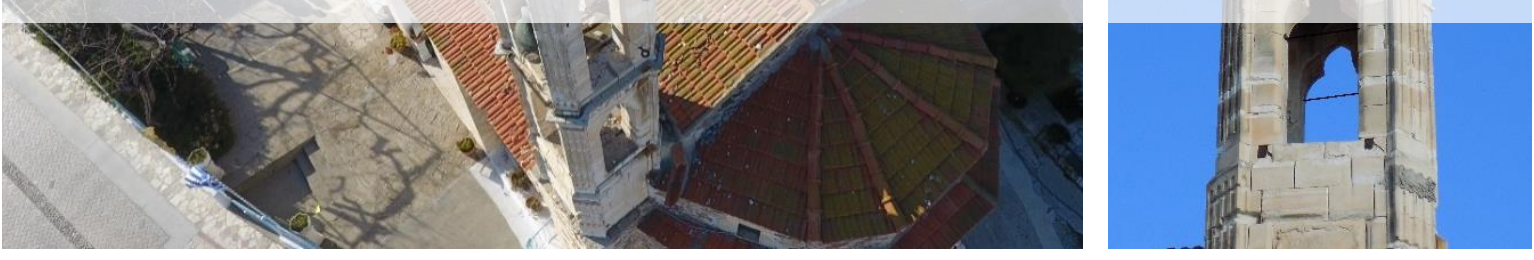

Figure 6: Bell tower of Saint John's church in Psevdas village after the earthquake (photos taken in February 2017)

The exposure of the iron elements of the bell tower to atmospheric oxygen and humidity led to corrosion. This resulted in cracked stone units and exposed anchorages of the cramps, which became visible at the exterior face of the bell tower (Fig. 6). This phenomenon was observed also in other cases, such as at the bell tower of Saint John's church in Larnaca (Fig. 7). However, cramps may not always become visible at an exterior wall face, as metal elements may have been placed in protected interior parts of the structure, which hinders the oxidation process from taking place. 


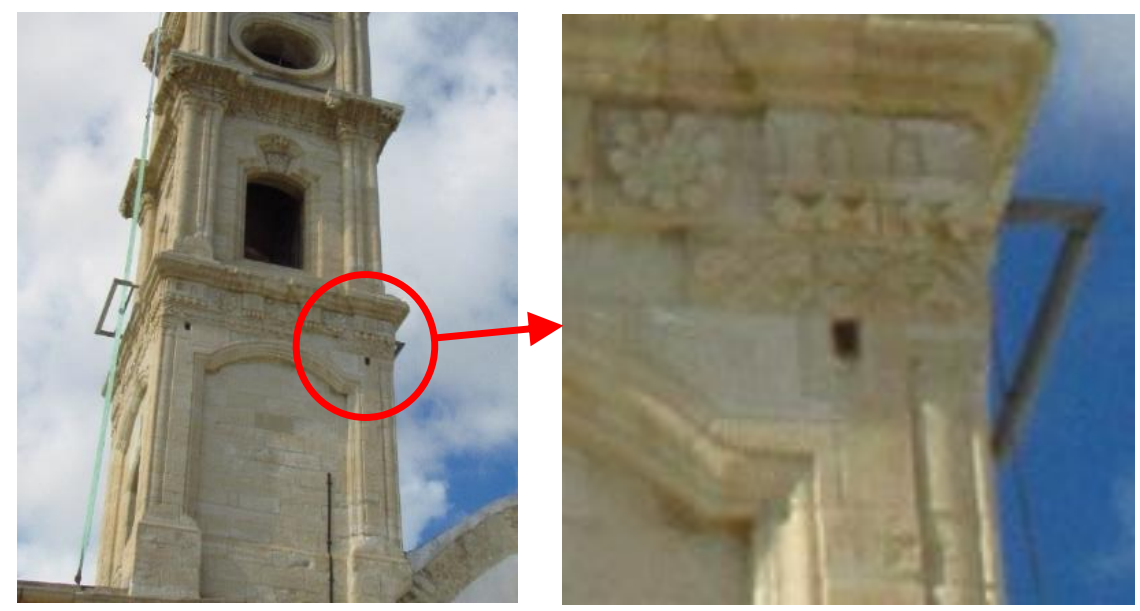

Figure 7: Bell tower of Saint John's church (left) Larnaca, where the anchorage of the cramns is visible (right)

Nonetheless, except for a few weathered stone units and some cracking around the metal elements, the overall condition of the survived part of the bell tower was good. It is quite clear that the damage actually occurred at the most sensitive and the only 'untied' part of the bell tower, the canopy.

\subsection{Restoration of the bell tower}

During the restoration works, the canopy and the whole upper part of the bell tow reconstructed to their original form. The replaced by similar stainless-steel elements. similar ones and the cracks were sealed with for the bell was installed, in order to prevent da mre

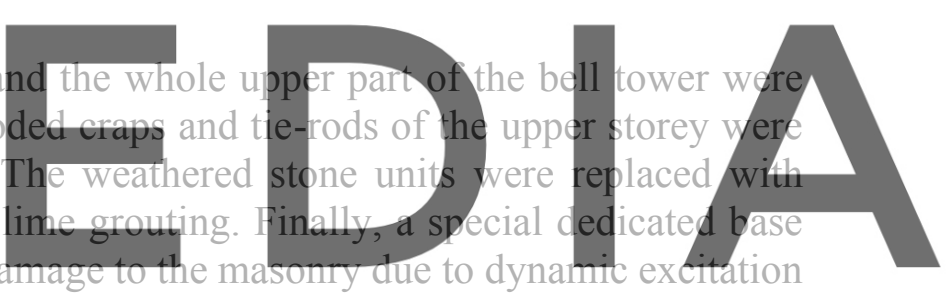
from the bell's swing and the corrosion of its iron base (Fig. 8).

Register for free at https//www.scipedia.com to download the version without the watermark
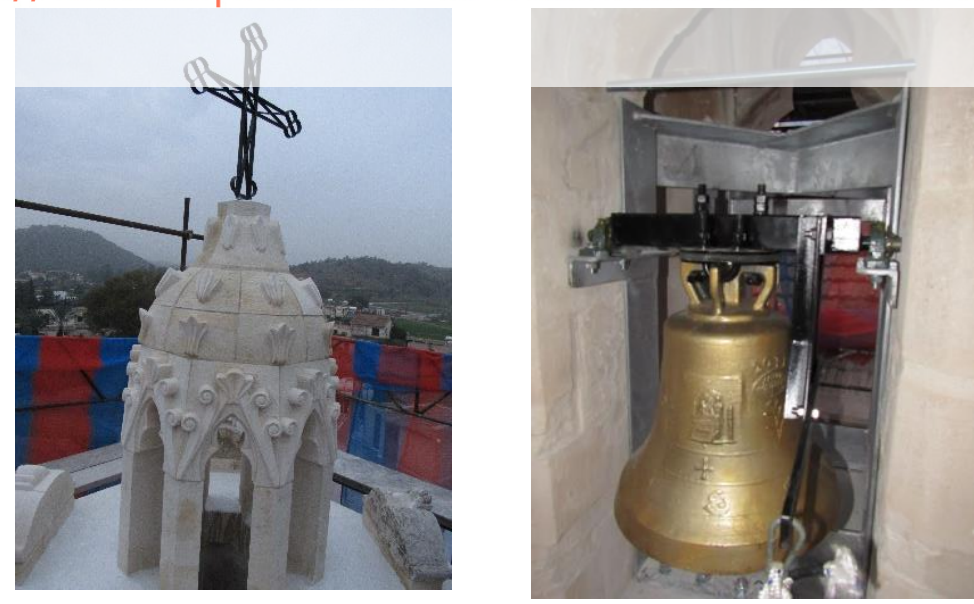

Figure 8: Restoration (left) and strengthening (right) of Saint John's bell tower in Psevdas (photos taken in December 2017) 


\section{CONCLUSIONS}

Bell towers appeared throughout the history of Cyprus as a symbol of religious and national freedom for the people on the island and emerged to be an integral part of the local ecclesiastical architecture. Ensuring the long-term safety and functionality of such traditional structures is a matter of heritage preservation. A major hazard opposed to the purpose of preservation is the significant seismic activity resulting from the 'Cyprean arc'.

The need to mitigate the earthquake hazard has led to the use of suitable technologies improving the seismic capacity of such structures. In particular, an approach widely applied in Cyprus is the installation of timber or iron tie-rods during initial construction of a bell tower. The contribution of such elements seems to be critical for the adequate long-term seismic resistance of traditional bell towers. The imperative need for effective tying is highlighted in the characteristic example presented in more detail in this work: the unfastened canopy of the Saint John church's bell tower in Psevdas village collapsed during a recent earthquake due to the absence of iron ties.

Although installed iron tie-rods are often encountered in traditional stone masonry structures all over the island of Cyprus, their application during construction was based on the then available empirical knowledge and intuition and lacks formal engineering validation following the current codes and established scientific knowledge. This induces a need for a campaign to study the traditional anchorage setup of iron ties and their effect on the structural behavior of masonry structures. The results of such studies will facilitate the structural assessment process and, if needed, the developnient of compatible restoration and strengthening technologies
respecting the traditional character of these structures.
Acknowledgements. The authors would like to acknowledge the contribution of Hercules
Charalambides and Constantinos Christou, who took the aerial photos presented and gave
concession for their use herein.

\section{Register farfreerattbttps//www.scipedia.com to download the version without the watermark}

[1] Damages on church due to earthquake in Larnaca (in Greek). Kathimerini, (2016).

[2] Kallinikou, C. The Christian temple and its rituals (in Greek). Grigoris Publications, (1969).

[3] Gatty, A. The Bell: Its Origin, History, and Uses. George Bell, 186, Fleet Street, (1848).

[4] Williams, E.V. The Bells of Russia: History and Technology. New Jersey: Princeton University Press, (1985).

[5] Kokkinoftas, C. The raise of bells on churhces in Cyprus during the Ottoman period (1571-1878) (in Greek). Church of Cyprus, (2018). [Online]. Available at: https://churchofcyprus.org.cy/41390. [Accessed: 09-Jan-2020].

[6] Myriantheus, D. The church of Panagia Phaneromeni, Nisocia. In: The Lady of Nicosia, Phaneromeni and the relics (in Greek), Bank of Cyprus Cultural Foundation (2012), pp. $15-25$.

[7] Emilianides, A. Religion and the state in dialogue: Cyprus. In: Religion and Law in Dialogue: Covenantal and Non-Covenantal Cooperation between State and Religion in Europe (2006), pp. 19-32.

[8] Kiessel, M. and Tozan, A. Orthodox Church Architecture in the Northern Districts of 
Cyprus from the mid-19th Century to 1974. Prostor, (2014).

[9] Myriantheus, D. Ecclesiastical Architecture (13th-20th century) (in Greek). In: The Holy Bishopric of Morphou. 2000 years of Art and Holiness (2000).

[10] Michaelides, S.G. Saint Lazarus - The history of the church in Larnaca" (in Greek). Holy

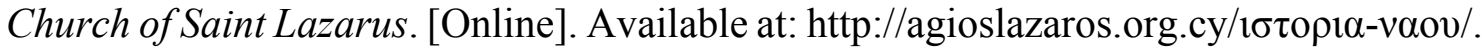
[Accessed: 30-Jan-2020].

[11] Lewis, M.J. The Gothic Revival. Thames \& Hydson, (2002).

[12] Baruffi, F., Boucher, J., Coryea, M. and Spector, D. VENICE BELLS AND BELL TOWERS A Striking Source of Knowledge. (2012).

[13] Constantinides, E. Monumental Painting in Cyprus during the Venetian Period, 14891571. In: C. Ševèenko et al. (Eds): Medieval Cyprus. Studies in Art, Architecture, and History in memory of Doula Mouriki, Princeton University Press (1999), pp. 263-300.

[14] J+A Filippou, Vitti, P. and De Vito, S. Church of Panagia Faneromeni, Nicosia: Architectural Interventions Report. (2016).

[15] Committee of the church of Panagia Phaneromeni. Holy Church of Panagia Phaneromeni (Nicosia): Official Memorial of the Archibishop Cyprianos and the Ethnomartyrs of 9th July 1821 (in Greek). Church of Cyprus, (2017). [Online]. Available at: https://churchofcyprus.org.cy/35384. [Accessed: 30-Jan-2020].

[16] Seismicity (in Greek). Cyprus Geological Survey Department. [Online]. Available at: http://www.moa.gov.cy/moa/gsd/gsd.nsf/page56_gr/page56_gr?OpenDocument. [Accessed: 30-Jan-2020].

[17] Strong Earthquake. Damages in Limassol (in Greek). Cypriot, (1906).

[18] Earthquakes (in Greek). Cyprus Geological Survey Department. [Online]. Available at: http://www.moa.gov.cy/moa/gsd/gsd.nsf/page40_gr/page40_gr?OpenDocument. [Accessed: 30-Jan-2020].

[19] Petrou, M. and Charmpis, D.C. Iron Ties Originally Anchored into Masonry as a Historical Construction Technology - Case Study: A Church in Cyprus. In: R. Aguilar et al. (Eds): Structural Analysis of Historical Constructions, RILEM Bookseries 18 (2019), pp. 153-161.

[20] Papageorgiou, A. and Committee of the Saint John's Cathedral. The Saint John's Cathedral. Church of Cyprus, (2019). [Online]. Available at: https://churchofcyprus.org.cy/9632. [Accessed: 30-Jan-2020].

[21] Sorrentino, L., Liberatore, L., Decanini, L.D. and Liberatore, D. The performance of churches in the 2012 Emilia earthquakes. Bulletin of Earthquake Engineering 12 (2014), pp. 2299-2331.

[22] Kouris, E.G. and Kouris, L.A. Investigation of the Influence of Tie-Rods on the Seismic Behaviour of Slender Towers. In: International Conference on Computational Structures Technology 12 (2018).

[23] Roca, P., Lourenco, P.B. and Gaetani, A. Historic Construction and Conservation. Materials, System and Damage. Taylor and Francis Group, (2019).

[24] Significant Earthquakes (in Greek). Cyprus Geological Survey Department. [Online]. Available at: http://www.moa.gov.cy/moa/gsd/gsd.nsf/All/AD24AEF6F60B0E14C22583C9004258A 9?OpenDocument [Accessed: 30-Jan-2020]. 